\title{
Hubungan Kausalitas Granger Harga Minyak Makan Nabati: Minyak Sawit, Minyak Kedelai, Minyak Canola, dan Minyak Biji Bunga Matahari
}

\author{
Granger Causality of Edible Vegeteable Oil Prices: \\ Palm Oil, Soy Bean Oil, Rapeseed Oil, and Sun Flower Oil \\ Devi Oktiani \\ Balai Riset dan Standardisasi Industri Bandar Lampung \\ Jl by pass Soekarno Hatta KM 1 Rajabasa \\ E-mail : divya_de_vi@yahoo.com
}

\begin{abstract}
Abstrak
Penelitian ini bertujuan untuk mengetahui hubungan kausalitas diantara minyak makan nabati yang banyak diperdagangkan di pasar internasional, yaitu minyak sawit, minyak kedelai, minyak kanola, dan minyak biji bunga matahari. Analisis dilakukan menggunakan metoda kausalitas Granger, data yang digunakan adalah data sekunder harga per bulan dari Januari 2009 hingga Januari 2017, berasal Kementerian Perdagangan. Diketahui bahwa terdapat hubungan kausalitas dua arah antara harga minyak biji bunga matahari dan harga minyak kanola, dan juga antara harga minyak bunga matahari dengan minyak kedelai, hubungan kausalitas satu arah terdapat pada harga minyak goreng sawit mempengaruhi harga minyak biji bunga matahari. Harga minyak goreng sawit tidak dipengaruhi secara signifikan oleh harga minyak nabati lainnya.
\end{abstract}

Kata kunci: minyak makan nabati, harga, Granger causality.

\begin{abstract}
The objective of this research is to analysis the causal relationship among vegetable edible oil which are traded in international market, they are palm oil, soy bean oil, rapeseed (canola) oil, and sun flower oil. The analysis based on Granger causality methods. The findings are there are two ways causality between sunflower oil and canola oil prices, and also between sunflower price and soy oil price, the one way causality is palm oil price effects the sun flower price. The oil palm price is not significantly affected by other vegetable edible oil prices.
\end{abstract}

Keywords: vegetable edible oil, palm oil, price, Granger causality.

\section{Pendahuluan}

Salah satu komoditas ekspor Indonesia adalah minyak kelapa sawit, salah satu produk utama minyak kelapa sawit adalah minyak goreng sawit. Di Indonesia sebagian besar masyarakat menggunakan minyak goreng yang berasal dari minyak kelapa sawit, kondisi ini berbeda dengan masyarakat di negara lain yang sudah umum menggunakan minyak goreng dari bahan lain selain kelapa sawit, sesuai dengan ketersediaan produk dan bahan baku pada setiap negara, yang mana hal ini dapat menyebabkan terdapat beberapa pilihan dalam konsumsi setiap jenis minyak nabati dan mempengaruhi pasokan dan harga tiap jenis minyak nabati.

Pada tahun 2018 dan tahun 2019 ini kecenderungan harga kelapa sawit semakin menurun. Penelitian sebelumnya telah melakukan analisis model penurunan harga kelapa sawit dan terlihat kecenderungannya menurun (Oktiani, 2018). Penurunan harga kelapa sawit yang berkelanjutan dapat mempengaruhi kinerja ekspor Indonesia, karena kelapa sawit merupakan salah satu komoditas ekspor utama Indonesia. Pada penelitian ini ingin dianalisis hubungan kausalitas antara harga komoditas minyak makan dengan salah satu objeknya adalah minyak goreng sawit. 
Badan Pengelola Dana Perkebunan (BPDP), (2019) sawit menyebutkan bahwa minyak nabati dunia yang paling banyak di konsumsi dan diperdagangkan adalah minyak kedelai (soybean oil), minyak sawit (palm oil), minyak rapeseed (canola) dan minyak bunga matahari (sunflower oil), sehingga keempat jenis minyak tersebut dipilih sebagai obyek atau variabel dalam penelitian ini. Lebih khusus lagi, dua jenis minyak nabati yang paling banyak dikonsumsi di dunia adalah minyak kelapa sawit dan minyak kedelai. Gabungan Pengusaha Kelapa Sawit Indonesia (GAPKI) (2019) menyebutkan bahwa dalam kurun waktu tahun 1965 - 2016 telah terjadi perubahan pola konsumsi minyak nabati di dunia, terdapat kecenderungan peningkatan konsumsi minyak sawit dari $22 \%$ pada tahun 1980 menjadi $39 \%$ pada tahun 2016, sebaliknya pangsa pasar minyak kedelai turun dari 55\% menjadi 33\% pada periode yang sama.

Menurut BPDP (2019), minyak kelapa sawit adalah jenis minyak nabati yang memiliki tingkat ekstraksi tertinggi dibanding dengan minyak nabati lainnya. Tingkat ekstraksi adalah jumlah produk minyak (MT) yang dapat dihasilkan dari setiap hektar lahan (ha). Tingkat ekstraksi minyak goreng sawit adalah sebesar 3,31 MT/ha, sedangkan minyak kedelai hanya sebesar 0,45 MT/ha dan minyak biji bunga matahari sebesar 0,7 MT/ha. Hal tersebut mengindikasikan bahwa produksi minyak goreng dari kelapa sawit adalah salah satu pilihan yang paling efisien disbanding dari bahan lain dari aspek pertimbangan penggunaan luas lahan.

Negara - negara di dunia dibagi menjadi empat jenis, berkaitan dengan karakteristik perdagangan minyak nabati (Gunstone, F.D., 2011), sebagai berikut:

a) Negara dengan populasi penduduk kecil yang memproduksi minyak atau biji minyak dalam jumlah besar, misalnya Australia, Malaysia, Canada, Argentina, dan Ukraina.

b) Negara dengan jumlah populasi penduduk besar yang memproduksi minyak atau biji minyak dalam jumlah besar untuk dapat mencukupi kebutuhan domestik dan masih dapat mengekspor, misalnya USA, Indonesia, dan Brazil.

c) Negara dengan jumlah populasi penduduk yang besar, yang mana jumlah impornya melebihi produksi domestik, yaitu China, India, India, Pakistan, Bangladesh, Sri Langka.

d) Negara yang berperan sebagai pedagang, yaitu memproduksi, mengkonsumsi, mengimpor, dan mengekspor produk, contohnya adalah negara - negara Uni Eropa, Hong Kong, dan Singapura.

Minyak kelapa sawit adalah minyak yang paling murah dibanding minyak nabati lainnya, sedangkan yang paling mahal adalah minyak biji bunga matahari. Minyak kedelai dan miyak canola pada awalnya memiliki harga yang hampir sama, tetapi pemanfaatan minyak canola sebagai bahan biodiesel menjadikan minyak canola memiliki harga jual yang lebih tinggi dibanding minyak kedelai (Gunstone, F.D., 2011). Kebijakan pengembangan biodiesel dari bahan yang biasa digunakan sebagai bahan minyak makan nabati mempengaruhi harga minyak nabati dari bahan tersebut.

Minyak Kelapa Sawit banyak diproduksi di Indonesia dan Malaysia, tetapi karena Indonesia lebih banyak mengkonsumsi minyak kelapa sawit berkaitan dengan jumlah populasinya yang besar, maka Malaysia lebih banyak mengekspor daripada Indonesia. Negara tujuan ekspor minyak kelapa sawit adalah China, Uni Eropa, dan India.

Minyak kedelai dan minyak jagung diproduksi dan dikonsumsi oleh USA, China, Argentina, Brazil, Uni Eropa, India. Negara pengekspor minyak kedelai adalah argentina, brazil, dan USA, sedangkan negara pengimpornya adalah China, India, dan Uni Eropa.

Minyak canola banyak diproduksi dan dikonsumsi oleh Uni Eropa, China, India, Canada, Japan. Negara pengekspor adalah Canada, sedangkan negara pengimpor adalah Uni Eropa dan China. Minyak biji bunga matahari banyak diproduksi di negara Rusia dan sekitar Rusia serta Argentina (Gunstone, F.D., 2011).

Francis In dan Bret Inder (1997) pernah meneliti tentang hubungan kausalitas antara harga minyak nabati, dan menyebutkan bahwa terdapat substitusi yang tinggi di antara minyak nabati yang diperdagangkan di pasar internasional. Hal tersebut menyebabkan harga minyak nabati di pasaran tidak mungkin berbeda jauh dari satu sama lain, setidaknya dalam jangka panjang. Dalam penelitian tersebut dilakukan analisis terhadap harga dunia dari delapan minyak nabati, selama periode waktu tertentu, dilakukan analisis terhadap hubungan jangka panjang. Penelitian tersebut menggunakan kerangka kointegrasi multivariat untuk analisis. Ditemukan bahwa terdapat empat vektor kointegrasi dalam model delapan variabel. Temuan empiris utama adalah bahwa ada kointegrasi atau hubungan jangka panjang antara minyak biji bunga matahari 
dengan minyak kedelai, dan juga antara minyak kedelai dan minyak biji matahari dan canola, hal tersebut mengidentifikasikan tingkat substitusi di antara mereka. Terdapat referensi yang menyebutkan tentang substitusi antara dua jenis minyak nabati minyak jagung dan minyak kedelai. Minyak jagung merupakan minyak nabati dalam urutan kesepuluh yang banyak dikonsumsi, tidak sebanyak minyak kelapa sawit dan minyak kedelai. Jagung dan kedelai memiliki beberapa karakteristik yang menyebabkan dua komoditas ini memiliki korelasi. Kedua komoditas ini merupakan produk yang bahan utama makanan manusia, merupakan bahan baku pakan ternak, dan hasil sampingnya dapat digunakan sebagai biodiesel. Kedua komoditas ini saling mensubstitusi dan juga saling melengkapi (Saghaian, 2017).

Minyak goreng sawit, minyak kedelai, minyak canola, dan minyak jagung memiliki fungsi sebagai minyak makan nabati atau sering disebut sebagi minyak goreng. Penggunaannya dapat saling mensubstitusi. Harga dan pasokan salah satu produk minyak dapat mempengaruhi demand (kebutuhan) jenis minyak yang lain. Harga dapat menjadi salah satu faktor yang dapat mempengaruhi konsumen dalam melakukan pemilihan produk, yang secara kolektif dapat mempengaruhi kesetimbangan harga, pasokan, dan demand. Tujuan penelitian ini adalah untuk menunjukkan hubungan kausalitas antara harga minyak, hubungan kausalitas

\section{Metode Penelitian}

\section{Data}

Data yang digunakan dalam penelitian ini adalah data deret waktu (time series) minyak sawit, minyak kedelai, minyak canola, dan minyak jagung setiap bulan dari bulan Januari 2009 hingga bulan Januari 2017. Data yang digunakan adalah data yang merepresentasikan harga di tingkat internasional. Data merupakan data deret waktu dengan interval waktu 1 bulan. Data harga tiap komoditas minyak didapatkan dari website Kementerian Perdagangan, merupakan data setiap bulan dari Januari 2009 hingga Januari 2017.

\section{Metode}

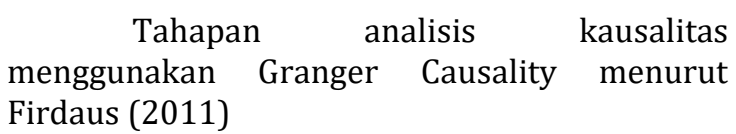

Tahapan dalam pengolahan data ini adalah sebagai berikut:
1. Melakukan uji stasionaritas masing masing variable pada level, menggunakan metoda uji root Augmented Dickey Fuller (ADF) test.

2. Melanjutkan uji stasioner pada turunan pertama (first difference) menggunakan metoda uji root Augmented Dickey Fuller (ADF) test.

3. Melakukan uji kausalitas dengan metoda Granger Causality. Granger Causality adalah suatu analisis yang dapat menyatakan bahwa suatu variabel $\mathrm{X}$ menyebabkan perubahan variabel $Y$, apabila nilai Y saat ini dapat diprediksi lebih baik dengan menggunakan nilainilai masa lalu variabel X. Uji kausalitas adalah suatu uji yang mengukur kekuatan hubungan antara dua variabel atau lebih, dan menunjukan arah hubungan antara variabel bebas dan variabel terikat. Studi kausalitas mempelajari hubungan sebab akibat.

4. Analisa data menggunakan software Eviews.

\section{Hasil Dan Pembahasan}

\section{Fluktuasi harga minyak makan nabati}

Gambar 1 menunjukkan fluktuasi harga setiap bulan minyak nabati dari komoditas sawit (PALM), kedelai (SOY), kanola (CANOLA), dan minyak biji bunga matahari (SUN) dari Januari 2009 hingga Januari 2017 (97 bulan). Pada gambar tersebut terlihat bahwa harga keempat komoditas tersebut mengalami yang tinggi kenaikan pada bulan ke 20 atau akhir tahun 2010, salah satu penyebab kenaikan harga ini adalah penggunaan minyak nabati sebagai bahan bakar atau biodiesel. Harga cenderung mengalami penurunan pada bulan ke 40 (awal tahun 2012). Masing - masing komoditas memiliki kurva fluktuatif yang tidak sama besar kenaikan penurunan maupun bulan atau waktunya., pada awal cenderung meningkat, kemudian menurun sejak awal tahun 2012.

Karakteristik industri minyak goreng sawit di Indonesia ini adalah bahwa minyak goreng sawit diproduksi oleh perusahaan - perusahaan besar. Sebagian besar perusahaan pembuat minyak goreng sawit tersebut juga memiliki kerjasama atau memiliki anak perusahaan berupa perusahaan perkebunan kelapa sawit dan juga perusahaan produsen minyak sawit mentah (crude palm oil ) atau CPO. Indonesia masih banyak mengekspor minyak sawit dalam 
bentuk CPO bukan dalam bentuk minyak goreng sawit atau refined bleached deodorized palm oil (RBDPO). Penurunan konsumsi minyak goreng sawit di pasar internasional dapat menyebabkan over suplai CPO, yang pada akhirnya menurunkan harga $\mathrm{CPO}$. adalah menggunakan uji unit root ADF (Firdaus, 2011).

\section{CANOLA}

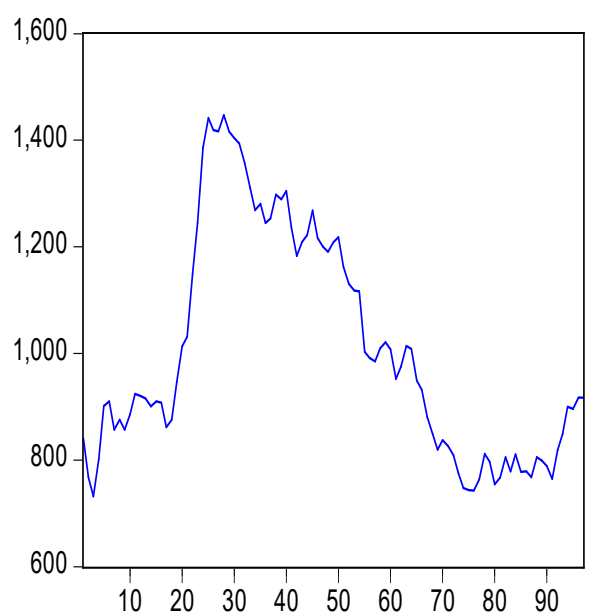

SOY

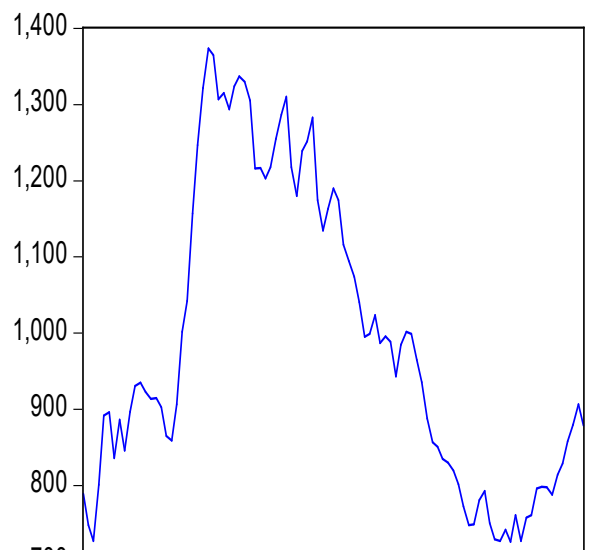

Keterangan : Sumbu Y = harga (US\$/ton) Sumbu $\mathrm{X}=$ bulan ke-
PALM

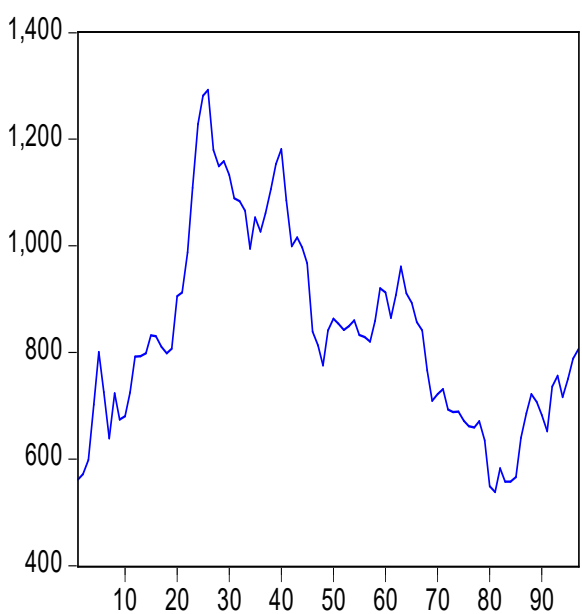

SUN

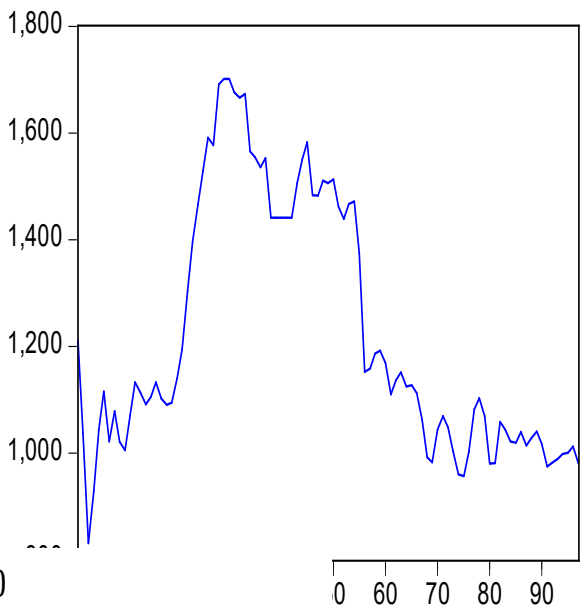

Gambar 1. Fluktuasi harga minyak sawit, minyak canola, minyak kedelai, dan minyak biji

\section{Analisis Kausalitas}

Suatu data time series dikatakan stasioner apabila memenuhi syarat -syarat sebagai berikut: rata - ratanya konstan, variannya konstan, dan kovarian antara dua periode waktu bergantung hanya pada jarak waktu antara dua periode waktu tersebut dan tidak bergantung pada periode waktu. Pada deret waktu yang stasioner pada dasarnya tidak ada gerakan trend yang bersifat sistematik. salah satu cara menguji stasionaritas data
Telah dilakukan uji stationaritas data masing masing komoditas pada level dan pada turunan pertama (frist difference). Uji Stasioner adalah uji yang dilakukan untuk mengetahui bahwa data time series tidak dipengaruhi oleh waktu. Hasil uji menunjukkan bahwa data pada level tidak stasioner sedangkan data pada turunan pertama stasioner, sehingga dapat dilakukan uji kausalitas menggunakan metoda granger causality. Stasioner merupakan suatu kondisi data time seriesyang jika rata-rata, 
variandan covarian dari perubah-perubah tersebut seluruhnya tidak dipengaruhi oleh waktu. Metode pengujian stasioneritas dan akar unit yang akan digunakan disini adalah metode Augmented Dickey Fuller (ADF) dan Phillips Perron (PP). Prosedur untuk mengetahui data stasioner atau tidak dengan cara membandingkan antara nilai statistik ADF atau PP dengan nilai kritis distribusi Mac Kinnon. Nilai statistik ADF atauPP ditunjukkan oleh nilai t statistik. Jika nilai absolut statistik ADF atauPP lebih besar dari nilai kritisnya, maka data yang diamati menunjukkan stasioner dan jika sebaliknya nilai statistik ADF atau PP lebih kecil dari nilai kritisnya maka data tidak stasioner.

Uji stasionaritas data pada level (Tabel 1) panjang Lag adalah 1. Nilai panjang lag yang digunakan adalah otomatis berdasr SIC, dengan maksimum Lag 11. Uji nilai probabilitas menggunakan metoda MacKinnon. Hasil uji stasionaritas data terdapat pada Tabel 1. Pada Tabel 1 terlihat bahwa nilai t-statistik ADF test masing - masing komoditas lebih kecil daripada nilai kritis t-statistik MacKinnon, sehingga dapat dikatakan bahwa data tidak stasioner, hal ini mengindikasikan bahwa harga dipengaruhi oleh waktu.

Tabel 1 Uji Stationaritas Data Menggunakan ADF Test

\begin{tabular}{ccc}
\hline Variabel & \multicolumn{2}{c}{ ADF test stasistik } \\
\cline { 2 - 3 } & Probabilitas & t-statistik \\
\hline PALM & 0,2449 & $-2,100940$ \\
SOY & 0,4800 & $-1,597428$ \\
CANOLA & 0,4588 & $-1,639098$ \\
SUN & 0,5146 & $-1,529274$ \\
\hline
\end{tabular}

Keterangan : Nilai pembanding t-statistik MacKinnon. Nilai kritis pada tingkat $1 \%=-3,500669$ Nilai kritis pada tingkat $5 \%=-2,892200$ Nilai kritis pada tingkat $10 \%=-2,583192$

Uji stasionaritas data pada turunan pertama (frist difference) ditunjukkan pada Tabel2. Pada Tabel 2 terlihat bahwa nilai tstatistik ADF test masing - masing komoditas lebih besar daripada nilai kritis t-statistik MacKinnon, sehingga dapat dikatakan bahwa data stasioner, hal ini mengindikasikan bahwa turunan pertama (selisih) harga dipengaruhi oleh waktu. Dapat dikatakan bahwa pada data data turunan pertama terkointegrasi.

Tabel 2 Uji Stationaritas Data Turunan Pertama (1 $1^{\text {st }}$ Differences)

\begin{tabular}{ccc}
\multicolumn{2}{c}{ Menggunakan ADF Test } \\
\hline Variabel & \multicolumn{2}{c}{ ADF test stasistik } \\
\cline { 2 - 3 } & Probabilitas & t-statistik \\
\hline D[PALM] & 0,0000 & $-7,290789$ \\
D[SOY] & 0,0000 & $-7,028436$
\end{tabular}

\begin{tabular}{rrr} 
D[CANOLA $]$ & 0,0000 & $-7,739876$ \\
D [SUN] & 0,0000 & $-6,818768$ \\
\hline Keterangan : Nilai pembanding t-statistik MacKinnon. \\
Nilai kritis pada tingkat $1 \%=-3,500669$ \\
Nilai kritis pada tingkat $5 \%=-2,892200$ \\
Nilai kritis pada tingkat $10 \%=-2,583192$
\end{tabular}

Syarat penggunaan Johansen Cointegration test adalah diterapkan pada data yang tidak stasioner, dan data harus berkointegrasi pada order yang sama. Uji stasionaritas pada level (Tabel 1) menunjukkan bahwa data tidak stasioner. Uji pada turunan pertama mengindikasikan bahwa data terkointegrasi. Dari kedua hal tersebut mengindikasikan bahwa dapat diterapkan uji kausalitas dengan metoda Johansen Cointegration test. Dilakukan uji Johansen cointegration test dengan 96 observasi (Tabel 3). Dari angka probabilitas pada data Tabel 3, dapat disimpulkan bahwa yang memiliki hubungan kauslitas adalah yang memiliki probabilitas $<0,05$.

Tabel 3 Johansen Cointegration Test

\begin{tabular}{|c|c|c|c|}
\hline Null Hypotesis (H0) & F-statistik & $\begin{array}{c}\text { Probabilita } \\
\text { S }\end{array}$ & $\begin{array}{c}\mathrm{H} 0 \\
\text { diterima/ditolak }\end{array}$ \\
\hline $\begin{array}{l}\text { PALM does not } \\
\text { Granger Cause } \\
\text { CANOLA }\end{array}$ & 2,90342 & 0,0917 & H0 diterima \\
\hline $\begin{array}{c}\text { CANOLA does not } \\
\text { Granger Cause PALM }\end{array}$ & 0,17004 & 0,6810 & H0 diterima \\
\hline $\begin{array}{l}\text { SOY does not } \\
\text { Granger Cause } \\
\text { CANOLA }\end{array}$ & 3,36779 & 0,0697 & H0 diterima \\
\hline $\begin{array}{l}\text { CANOLA does not } \\
\text { Granger Cause SOY }\end{array}$ & 0,14087 & 0,7083 & H0 diterima \\
\hline $\begin{array}{c}\text { SUN does not } \\
\text { Granger Cause } \\
\text { CANOLA }\end{array}$ & 10,8558 & 0,0014 & H0 ditolak \\
\hline $\begin{array}{l}\text { CANOLA does not } \\
\text { Granger Cause SUN }\end{array}$ & 32,0640 & $2.10^{-7}$ & H0 ditolak \\
\hline $\begin{array}{c}\text { SOY does not } \\
\text { Granger Cause PALM }\end{array}$ & 0,22450 & 0,6367 & H0 diterima \\
\hline $\begin{array}{c}\text { PALM does not } \\
\text { Granger Cause SOY }\end{array}$ & 1,40850 & 0,2383 & H0 diterima \\
\hline $\begin{array}{c}\text { SUN does not } \\
\text { Granger Cause PALM }\end{array}$ & 1,04083 & 0,3103 & H0 diterima \\
\hline $\begin{array}{c}\text { PALM does not } \\
\text { Granger Cause SUN }\end{array}$ & 12,250 & 0,0008 & H0 ditolak \\
\hline $\begin{array}{c}\text { SUN does not } \\
\text { Granger Cause SOY }\end{array}$ & 6,09652 & 0,0154 & H0 ditolak \\
\hline $\begin{array}{c}\text { SOY does not } \\
\text { Granger Cause SUN }\end{array}$ & 26,4401 & $2.10^{-6}$ & H0 ditolak \\
\hline
\end{tabular}

Pasar minyak nabati dipengaruhi oleh jumlah pasokan dan kebutuhan, dan harganya cenderung mengalami peningkatan, karakteristik dari harga minyak adalah tidak dipengaruhi oleh musim dan siklus. Harga minyak sawit lebih rendah daripada minyak kedelai, meskipun minyak sawit telah mendominasi pasar, produksi, dan konsumsi. Faktor yang paling menentukan harga minyak sawit adalah jumlah pasokan dan kebutuhan 
(Abdullah, 2013). Hubungan antara pasokan dan harga minyak nabati,khususnya minyak sawit telah diteliti oleh Ruijin (2017). Terdapat hubungan kausalitas jangka pendek antara produksi terhadap harga, dan juga antara ekspor dengan harga minyak goreng sawit (Hassan dan Balu, 2016).

Terdapat hubungan kausalitas antara harga minyak biji bunga matahari dan harga minyak kanola, hal ini dapat disebabkan karena dua produk ini memiliki pangsa pasar yang sama sehingga kedua produk ini saling mensubstitusi. Kedua produk ini banyak diproduksi di Argentina dan dikonsumsi oleh masyarakat Argentina dan Uni Eropa.

Demikian juga terdapat hubungan kausalitas dua arah antara harga minyak bunga matahari dengan minyak kedelai. Hal ini mengindikasikan bahwa harga kedua komoditas ini saling mempengaruhi. Kedua produk ini juga banyak diproduksi di Argentina dan dikonsumsi oleh masyarakat Argentina, Uni Eropa, dan USA.

Hubungan kausalitas antara harga minyak goreng sawit dengan minyak biji bunga matahari adalah hubungan satu arah. Harga minyak goreng sawit mempengaruhi harga minyak biji bunga matahari, hubungan ini tidak berlaku sebaliknya, dapat dikatakan bahwa harga minyak biji bunga matahari tidak memperngaruhi harga minyak goreng sawit.

Tidak terdapat hubungan kausalitas antara minyak goreng sawit dengan minyak kanola. Demikian juga tidak terdapat hubungan kausalitas antara minyak kedelai dengan minyak kanola. Hubungan kausalitas juga tidak terdapat pada harga antara minyak kedelai dan minyak goreng sawit.

Mencermati hubungan kausalitas tersebut, dapat diintrepretasikan bahwa harga minyak goreng sawit di pasar dunia tidak dipengaruhi secara signifikan oleh harga minyak - minyak nabati yang lain, dlam hal ini minyak kedelai, minyak canola, dan minyak biji bunga matahari. Hal ini dapat dipahami, karena harga minyak goreng sawit ini adalah lebih murah dibanding dengan minyak - minyak nabati lainnya. Harga minyak goreng sawit yang lebih murah dibanding minyak nabati lain ini merupakan salah satu keunggulan, akan tetapi harga yang murah ini juga masih mengalami kecenderungan penurunan harga dan oversuplai pasokan. Pengolahan minyak sawit menjadi produk produk hilir yang lain selain minyak goreng sawit akan dapat menjaga kestabilan harga dan meningkatkan nilai tambah kelapa sawit. Publikasi tentang manfaat dan keunggulan produk minyak goreng sawit akan dapat memperbaiki persepsi masyarakat dunia terhadap minyak goreng sawit dan memperluas pasar minyak goreng sawit.

\section{Kesimpulan}

Terdapat hubungan kausalitas dua arah antara harga minyak biji bunga matahari dan harga minyak kanola, dan juga antara harga minyak bunga matahari dengan minyak kedelai. Hubungan kausalitas satu arah terdapat pada harga minyak goreng sawit mempengaruhi harga minyak biji bunga matahari. Harga minyak goreng sawit tidak dipengaruhi secara signifikan oleh harga minyak nabati lainnya.

\section{Daftar Pustaka}

Abdullah, R. (2013). An Analysis on Trends of Vegetable Oil Prices, and Some Factors Affecting CPO Price. Oil Palm Industry Economic Journal, 13(2), 1-14.

Gabungan Pengusaha Kelapa Sawit Indonesia (GAPKI) website: https://gapki.id/news/6282/mitos-8-01dunia-lebih-sukai-minyak-kedelai-rapeseedbunga-matahari-bukan-minyak-sawit diakses tanggal 3 Maret 2019 pukul 11.00.

Badan Pengelola Dana Perkebunan, Website: https://www.bpdp.or.id/id/sawitberkelanjutan/pasar-minyak-nabati-dunia/ diakses tanggal 1 Maret 2019 pukul 11.00.

Firdaus,M. (2011), Aplikasi Ekonometrika Untuk Data Panel dan Time Series, PT Penerbit IPB Press Bogor.

Gunstone, F.D. " Production and Trade of Vegetable Oils", dalam "Vegetables Oils in Food Technology: Composition, Properties, and Uses, 2nd ed. Edited by Gunstone, F.D. 2011, United Kingdom : Blackwell Publishing Ltd., A John Wiley @ Sons Ltd Publication , https://books.google.co.id/books?hl=en\&lr= \&id=lnk2tdo8 P4C\&oi=fnd\&pg=PA1\&dq=pal $\underline{m++o i l+s o y+o i l++ \text { edible }+ \text { oil }+ \text { price \&ots }=2 Z \mathrm{Ll}}$ vb7QYM\&sig=MbOGYMCcA B8eNnkwEerUW 448ks\&redir esc $=y \# v=$ onepage $\& \mathrm{q}=$ palm $\% 2$ 0\%20oil\%20soy\%20oil\%20\%20edible\%20o il\%20price\&f=false

Hassan, A. dan Balu, N. (2016). Examining the Long Term Relationship between The Prices of Palm Oil and Soyabean Oil, Palm Oil Production and Export: Cointegration and Causality. Oil Palm Industry Economic Journal, 16(1), 31-37.

In, Francis and Inder, B. (1997). Long-run relationship between world vegetable oil prices. Resource Economics 41:4, 455 - 470. 
Kementerian Perdagangan, website : https://www.kemendag.go.id/id/economicprofile/prices/international-pricetable?year $=2009$ Diakses : 01 Mei 2019.

Oktiani, D. (2018). Pemodelan Harga CPO Indonesia Tahun 2018 dengan ARIMA. Majalah Teknologi Agro Industri (TEGI), 10(2), 33-41. http://ejournal.kemenperin.go.id/tegi/articl e/view/4399/pdf 4

Ruijin, L. dan ChengLi, W (2017), Dynamic Relationship Analysis Between Palm Oil Supply Shocks and Domestic Vegetable Oil Prices Volatility. Journal of Shouthern Agriculture, 48 (4), $739 \quad-747$. https://www.cabdirect.org/cabdirect/abstra ct/20173173437.

Saghaian, S. Y. [2017] "Export Demand Estimation for U.S. corn and soybean to major destinations". Theses and Dissertations--Agricultural Economics. 53. https://uknowledge.uky.edu/agecon etds/5 $\underline{3}$ 